\title{
Comparative Study on Competitiveness between Port of Fuzhou and Port of Taipei
}

\author{
Minru Yan \\ Logistics Department, Economics and Management College, Fuzhou University, Fuzhou, 350116, \\ China
}

Keywords: port of Fuzhou; port of Taipei; competitiveness; countermeasures

\begin{abstract}
With continuous development of economic globalization, the global trade link becomes closer and closer; some new changes happen in international shipping industry, which causes great influence on function layout of port. In order to fight for the position of shipping center, the competition between important ports becomes increasingly intense. The port of Fuzhou is located in Taiwan Strait region which takes Fuzhou, Xiamen, Taipei and Gaoxiong as core, and it is one of coastal key container artery ports in the west coast of the Taiwan Strait and only second to port of Xiamen. There exists great competition between the port of Fuzhou as an important international goods turnover port and the second biggest port - port of Taipei in Taiwan. This paper carries out comparative analysis on main advantages and disadvantages in terms of competitive force between port of Fuzhou and port of Taipei, and also gives a discussion on countermeasures about improving competitiveness of port of Fuzhou.
\end{abstract}

\section{Contrastive analysis on current situation of port of Fuzhou and port of Taipei}

(I) Current situation of port of Fuzhou

The port of Fuzhou is a comprehensive port which is mainly used for handling container, bulk cargo, and passenger transport in China's south-east coastal area, and the main port area is distributed in Minjiang River estuary section, such as port of Taijiang area, port of Mawei area, port of Qingzhou area, port of Songmen area, port of Choudong area, and port of guantou area. By the end of 2013, the port of Fuzhou owns 162 productive berths, including 45 deep water berths, and 50,000 ton-level container ship can berth in this port. The port of Fuzhou mainly operates energy, raw materials, mineral building materials, container, and other transportation services. The cargo handling capacity of port in 2013 is more than 110 million ton, the container handling capacity is 2.14 million TEU, and such capacity is ranked at the $18^{\text {th }}$ place in China. Its cargo handling capacity and container handling capacity are only second to that of port of Xiamen in Fujian province, and it is the second biggest port in the west coast of the Taiwan Straits. Furthermore, this port has navigation contact with almost 100 ports in almost 50 countries and regions; so far, there are totally 12 international regular liner ship lines opened in the port of Fuzhou, and the monthly average number of international flights reaching the port at average is 320. Besides, there is dedicated railway line through which it is able to directly arrive at wharf in port of Fuzhou, thus the cargo transfer is very convenient.

(II) Current situation of port of Taipei

The port of Taipei is located in Bali Village, Taipei County, Taiwan, and it is one of main international commercial ports in Taiwan province. The construction of port is positioned as auxiliary port of port of Keelung, and the main business is container transportation. However, the port of Taipei has a port area larger than the port of Keelung; in the future, it is expected that the port of Taipei will replace the port of Keelung and become the largest container wharf in Taiwan region. Currently, the port of Taipei bears about 35\% of cargo handling capacity in Taiwan region, and the container handling capacity accounts for about $30 \%$ of total container handling capacity of ports in Taiwan; the sea transportation network is throughout the world, and 272 ship routes have been opened. Currently, the monthly average number of incoming ships is about 1,100 ship-time; the deep water berth at port of Taipei has a water depth of above $15 \mathrm{~m}$, thus the large-scale container ship can berth in this port. The container cargo handling capacity of port accounts for about $40 \%$ of total cargo handling capacity, and the main navigation area is Southeast Asia, European and 
American area.

\section{Analysis on main problems existing in port of Fuzhou}

Since the reform and opening-up, China has a quick economic development, and the domestic and international trade volume increases rapidly. Under this background, the container transportation of port of Fuzhou obtains great development; however, in the development process, there also exists several problems.

(I) Low ship route and flight density

Currently, there are 134 container liner ship lines operated in port of Fuzhou, including 45 ocean routes. Compared to other large-scale ports in this region, the port of Fuzhou has few ship lines and low density of ocean artery flight.

(II) Imperfect water-land coordinated transport system, which influences radiation effect of port

The direct hinderland scope of port of Fuzhou includes Fuzhou City, Nanping City, and most part of Sanming City and Ningde City. The indirect hinderland scope includes east part of Jiangxi province and Hunan province as well as southern region of Sanming City and northern region of Putian City. Most of hinderland of port of Fuzhou are in Fujian province; as the depth hinderland of port, Hunan and Jiangxi province face the situation of being parted by port group in Yangtze River Delta and Pearl River Delta area. Currently, although 4 railways have been newly built in Fujian, the position of Fujian as "end" of national railway network is not thoroughly changed. Therefore, generally speaking, the traffic infrastructure of Fujian province is till imperfect. This greatly influences development of port of Fuzhou and improvement of competitive force.

(III) Insufficient port infrastructure

The port of Fuzhou has many container wharfs, but the structural contradiction is still outstanding; in particular, the shipping route in main port area has an insufficient water depth. Except for newly-built few container wharfs, other berths generally have a low grade, and the modernized large-scale container ship can't berth on those berths. There are 6 shallows in port shipping route, thus the 10,000 ton-level seagoing vessel can enter and leave the port only when the tide happens, and the 30,000 ton-level seagoing vessel can enter and leave the port only when the spring tide happens. The shipping route in north port has a length of $16.4 \mathrm{~km}$; due to narrow surface of rive, only seagoing vessel below 1,500 ton level can pass the port under the condition of navigation under tide. However, the shipping route in south port is seasonable navigation route; because the shipping route has insufficient ability to make large-scale ship pass, it is difficult for the port to adapt to current trend of larger-sized vessel. Through comparison, the port of Xiamen has great competitive advantage in terms of berthing of modernized container ship due to advantageous geographical position, large depth of navigable channel.

(IV) Insufficient port hinterland resources

The direct hinderland scope of port of Fuzhou includes Fuzhou City, Nanping City, and most part of Sanming City and Ningde City. The indirect hinderland scope includes east part of Jiangxi province and Hunan province as well as southern region of Sanming City and northern region of Putian City. The limited cargo resources restrict development of port.

(1) The port of Fuzhou is located at the west coast of Taiwan Strait, the Yangtze River Delta and Pearl River Delta area, both of which are two economic zones with the highest economic development and the biggest economic aggregate in China, lies at the south and north part respectively. Due to squeezing of these two economic zones, the west coast of Taiwan Strait economic zone where the port of Fuzhou is located has a small economic aggregate. Therefore, currently, although the port of Fuzhou has a rapid development, due to insufficient economic aggregate of hinterland and limited cargo volume, the development lacks of delayed effect. In recent years, the annual average growth of container handling capacity of port of Fuzhou is lower than that of ports in Shanghai, Shenzhen, Tianjin, and Guangzhou, etc. in economic developed area; the gap between port of Fuzhou and other domestic large ports continuously expands.

(2) Due to intensified competition between ports in local area, the loss risk of source of goods in the port of Fuzhou is intensified. In recent years, Xiamen and Quanzhou expand the port 
construction, thus the competition with port of Fuzhou is further intensified, and the fighting for source of goods between ports is very intense. In the past, the port of Quanzhou had a small scale, and most of foreign trade in Quanzhou region was made through the port of Fuzhou. However, in recent years, the port of Quanzhou expands port construction, and proposes the development objective of constructing 100 million ton-level port; due to continuous improvement of port facilities and service level, the cargos in Quanzhou region are shipped in the port of Quanzhou due to geographic position factor, which constitutes great threat to the port of Fuzhou.

\section{Main reasons for decrease of competitiveness of port of Taipei}

(I) Taiwan has a poor macro economy, and the traditional industries seriously wither.

In recent years, the growth of Taiwan economy gradually slows down; meanwhile, the land cost and labor cost in Taiwan continuously raise; this causes dramatic increase of enterprise cost; therefore, the competitive ability of labor-intensive industry greatly declines and it is gradually replaced of high-tech industry. Because the high-tech products have small volume, light quality and high value, they are often transported by air, which causes decrease of cargo volume in port and makes the increase in throughput of port of Taipei become weak.

(II) The competitiveness of main port continuously improves due to rapid increase of mainland economy.

Due to relatively cheap land cost and salary in mainland region, the mainland region has great advantage in labor-intensive industry; therefore, the mainland region undertakes a big transfer of global manufacturing industry and becomes a global manufacturing center honored as "world factory", which causes great increase in import and export volume. Under this background, the throughput of ports in Shanghai and Shenzhen, etc. continuously have a high-speed increase, which causes great competitive pressure on other ports in East Asia.

(III) Partial shipping firms leave due to no direct navigation between Taiwan and mainland.

In recent years, the main ports in East Asia region neighboring to Taiwan enhance the infrastructure construction, and attract affiliation of ships by virtue of good service and favorable measures. Due to no direct navigation between Taiwan and mainland, many shipping firms are attracted by wide market in mainland China and add affiliation of ships into ports in mainland. Meanwhile, the containers of mainland enterprises rarely make use of the port of Taipei as transshipment port, which makes the competitive advantage of port of Taipei gradually decline. A trend of marginalization appears in the port of Taipei.

(IV) The infrastructure construction of port has a slow updating.

Although the port of Taipei has a large area, there are not many container wharfs; currently, the utilization rate is almost under saturation condition. Although the port of Taipei currently plans to additionally build container wharf, the construction progress is very slow, and the wharf can't be completed and put into operation within short term. Furthermore, the shipping firms can't coordinate with middle and long-term planning, thus they have to reduce the shipping route of affiliation to port of Taipei.

\section{Analysis on development prospect of port of Fuzhou and port of Taipei}

(I) Positioning and future development prediction of port of Fuzhou

The port of Fuzhou is the second biggest port in China's south-east coastal areas; Fujian province positions Fuzhou as an important center city of "constructing west coast of Taiwan Strait economic zone”, and China also gives key support to development of ports such as port of Fuzhou, port of Xiamen, and Meizhou Bay. In China's port layout planning, the port of Fuzhou is determined to develop offshore, internal branch container, bulk cargo and sundry goods transportation. In future development planning, the port of Fuzhou will take container transportation as key development direction, and also pay attention to harmonious development of other freight and passenger transport; the port of Fuzhou will pay key attention to developing open sea deep water port area. Jiangyin port area mainly constructs the west operation area van container wharf, east operation 
area metallurgy deepwater berth will be built; Luoyuan Bay port area mainly constructs Kemen operation area, Jiangjunmao operation area large-scale energy and mineral deepwater berth. Minjiang River estuary and Songxia port area respectively construct Chang'an and Yangyu operation area container transportation as well as coastal industrial area port industry berth. In this way, the port of Fuzhou is gradually developed as international large port and regional logistics center.

(II) Positioning and future development prediction of port of Taipei

The future port positioning of port of Taipei is regional shipping hub and foreign transshipment center. However, in order to realize this objective, it is required to undertake the foreign trade transport demand caused by economic development of mainland, and it is necessary for both sides of Taiwan Straits to realize "three direct links". In recent years, due to alleviation of relation between both sides of Taiwan Straits, the economics and trade relation between both sides of Taiwan Straits have a good development, and the trade volume between both sides continuously increases. According to relevant experts' prediction, the cross-strait trade will cause about 3.8 million TEU freight volume in 2015, and most of those cargos will be shipped and transferred through port of Taipei. The biggest advantage of port of Taipei is its advantageous geographic position and natural condition; only if the port of Taipei quicken its infrastructure construction, improves service level, and opens direct "three links" between both sides as soon as possible, it can effectively attract mainland cargos to make transshipment in port of Taipei. Otherwise, with quick development of ports in China's south-east coastal area, it is very likely that the future container transshipment continues to make transfer in those ports, and the cargo throughput and competitiveness of port of Taipei will continue to decline.

\section{Analysis on countermeasures about improving competitiveness of port of Fuzhou}

(I) To perfect the shipment link of port with inland hinderland

Due to continuous development of economic globalization, the economic and trade contact around the world continuously increases; therefore, the ports gradually become the most important node in logistics. Currently, the goods traffic has not directly selected port any more, but selected complete logistics supply chain; only after the port and inland hinderland make use of various modes of transport to form efficient combined transportation logistics system, the port can effectively attract source of goods and improve its competitiveness. Therefore, it is required to actively promote the construction of transport network which takes railway connecting port of Fuzhou, Jiangxi, Hunan and other inland hinderland, and expressway as artery, and further improve the collecting and distributing ability of port of Fuzhou.

(II) To quicken infrastructure construction of port

The giant container vessel is the development trend of future container carrier. In order to face this change, the port of Fuzhou shall further quicken the construction of container deepwater berth; meanwhile, the main route of port of Fuzhou, and route in north and south port area shall be further expanded and deepened on the original basis. Besides, it is also required to expand the storage in port area, construction of service function area in bonded area, and improve construction standard of port area and rear roads. In order to realize the objective of constructing international large port and shipping center, the port of Fuzhou must adopt many ways to attract various large-scale vessel companies in the world to participate in construction and operation of port of Fuzhou; for example, it is able to adopt joint-ventured construction of new wharf to allow vessel companies to have self-running of their specialized wharf. This not only solves partial financial gap of port construction, but also brings more businesses to port of Fuzhou and improves competitiveness of port compared to other ports in the area due to vessel companies' addition of affiliation to port of Fuzhou.

(III) To uniformly carry out port group planning at the west coast of the Taiwan Strait so as to form group advantage and realize joint development

Due to development of international container transportation industry, the East Asia region becomes a region with most intense international competition among ports. As for this, Fujian 
province carries out overall planning for container ports in whole province, including port of Fuzhou and port of Xiamen; in the planning, as the second biggest port in local area, the port of Fuzhou is determined as regional transfer hub port. The port of Fuzhou shall carry out overall planning in which the respective advantages can be complementary to each other according to different positioning of various port in the area; only after the cluster advantage is formed, it is able to effectively confront the intense competition between ports in this area.

\section{Conclusion}

With continuous deepening of economic globalization, the global trade volume and category of goods continuously increase, and a great influence is caused on international shipping industry and port function layout; furthermore, a new tide of port construction and fierce competition among important ports are triggered. The port of Fuzhou and port of Taipei are regional large ports, and they are also the second biggest port in Fujian province and Taiwan province respectively as well as important regional container transshipment center. Due to similar port positioning, there exists great comparability at various aspects of two ports. This paper carries out comparison and analysis on development status, existing problems, and development prospect of two ports, and these two ports have respective competitive advantages and disadvantages. According to current situation, driven by economic development of mainland, the port of Fuzhou has higher improvement speed in terms of port construction and competitiveness than the port of Taipei, and it is under advantageous situation in regional competition. Finally, this paper also proposes some measures and suggestions for quickening the construction of port of Fuzhou.

\section{References}

[1] Shen Qingqiong: Countermeasures for Logistics Development of Port of Fuzhou [J], China Water Transport, issue 5 of 2009

[2] Huang Minsheng, Li Wenshi, Wu Pingqi: Analysis on Progress of Three Links Between Both Sides of Taiwan Strait and Research on Fujian-Taiwan Direct Route Strategy [J], Economic Geography, issue 4 of 2003

[3] Zhao Mo: Research on Trade Competitiveness of China's Maritime Transport Service [D], Dalian Maritime University, 2011

[4] Dong Gang: Research on Theory and Application of Modern Port Competitiveness [D], Fudan University, 2011

[5] Yan Wuyuan: Research on Multi-objective Decision and Intelligent Optimization of Container Wharf Layout Scheme [D], Wuhan University of Technology, 2007 